\title{
GAMBARAN KARAKTERISTIK AKSEPTOR KB SUNTIK 3 BULAN DENGAN AMENOREA SEKUNDER DI BPM BIDAN "S" CURUG TANGERANG 2017
}

\author{
Putri Handayani Setyaningsih \\ Sekolah Tinggi Ilmu Kesehatan Widya Dharma Husada Tangerang \\ E-mail: putri_yupi87@yahoo.com
}

\begin{abstract}
ABSTRAK
Berdasarkan hasil survey Januari - April 2017 jumlah aksetor KB suntik 3 bulan di BPM Bidan "S" Curug Tangerang sebanyak 425 orang. Dari data tersebut didapat akseptor KB suntik 3 bulan yang tidak mengalami efek samping yaitu 98 23\%, dan yang mengalami efek samping dari KB suntik 3 bulan sebanyak $77 \%$, terdiri dari yang mengalami amenore sebanyak 75\%, yang mengalami kenaikan berat badan sebanyak 19,5\%, dan yang mengalami spoting 5,5\%. Tujuan dalam penelitian ini yaitu untuk mengetahui gambaran karakteristik akseptor KB suntik 3 bulan dengan amenorea sekunder berdasarkan usia, paritas, lama KB, lama mengalami gangguan haid. Metodologi dalam karya tulis ini menggunakan jenis metode deskriptif. Tempat adalah BPM Bidan "S" Curug Tangerang. Desain penelitian yang dipakai adalah "Cross Sectional". Dengan jumlah populasi 315 orang. Besar sampel yang diambil 76 responden dan tekhnik pengambilan samplenya dengan "Non Probability Sampling" metode yang digunakan adalah "Accidental sampling". Data dikumpulkan dengan data sekunder melalui rekam medik. Analisa data yang digunakan adalah analisa univariat. Hasil penelitian yang diperoleh yaitu berdasarkan usia, 76 lebih dari setengahnya berusia 20-35 sebayak 56 orang $(73,7 \%)$. Berdasarkan paritas, dari 76 lebih dari setengahnya akseptor grande multipara sebanyak 48 orang $(63,1 \%)$. Berdasarkan lama ber-KB dari 76 setengahnya dengan lama berKB $\geq 24$ bulan sebanyak 41 orang. Berdasarkan lama mengalami gangguan dari 76 kurang dari setengahnya mengalami gangguan haid $6-10$ tahun sebanyak 31 orang.
\end{abstract}

Kata Kunci : : Akseptor, KB hormonal, Amenorea Sekunder

\begin{abstract}
Based on the survey results of January - April 2017 aksetor number of injections 3 months in Midwives BPM "S" Curug Tangerang as many as 425 people. From the data obtained acceptor injections three months did not experience any side effects that 23\%, and who experience side effects from injections of 3 months as many as $77 \%$, consisting of amenorrhea were $75 \%$, which experienced a weight gain as many as $19.5 \%$, and those with spoting $5.5 \%$. The purpose of this research is to describe the characteristics of 3-month injectable acceptors with secondary amenorrhea by age, parity, KB long, long experienced menstrual disorders. The methodology in this paper uses descriptive method types. The place is BPM Midwives "S" Curug Tangerang. The study design used is "Cross Sectional". With a population of 315 people. Large samples taken 76 respondents and retrieval techniques samplenya with "Non-Probability Sampling" method used was "accidental sampling". Data collected by the secondary data through medical records. Analysis of the data used univariate analysis. The results obtained are based on age, 76 more than half sebayak 56 people aged 20-35 (73.7\%). Based on parity, more than half of the 76 acceptors grande multipara many as 48 people (63.1\%). Based on the old family planning with a long of 76 half berKB $\geq 24$ months as many as 41 people. Based on long experience disruption of 76 is less than half as many menstrual disorders 6-10 years as many as 31 people.
\end{abstract}

Keywords $\quad$ : Acceptor, hormonal birth control, Secondary amenorrhoea. 


\section{PENDAHULUAN}

Keluarga Berencana menurut WHO (World Health Organization) adalah tindakan yang membantu individu atau pasangan suami istri untuk mendapatkan objek-objek tertentu, menghindari kelahiran yang tidak diinginkan, mendapatkan kelahiran yang memang diinginkan, mengatur interval diantara kehamilan, mengontrol waktu saat-saat kelahiran dalam hubungan dengan umur suami istri, dan untuk menentukan jumlah anak dalam keluarga. Sejalan dengan Peraturan Pemerintah Republik Indonesia Nomor 87 Tahun 2014 Tentang Perkembangan Kependudukan Dan Pembangunan Keluarga, Keluarga Berencana, Dan Sistem Informasi Keluarga, program Keluarga Berencana (KB) merupakan salah satu strategi untuk mengurangi kematian ibu khususnya ibu dengan kondisi 4T; terlalu muda melahirkan (di bawah usia 20 tahun), terlalu sering melahirkan, terlalu dekat jarak melahirkan, dan terlalu tua melahirkan (di atas usia 35 tahun). Selain itu, program KB juga bertujuan untuk meningkatkan kualitas keluarga agar dapat timbul rasa aman, tentram, dan harapan masa depan yang lebih baik dalam mewujudkan kesejahteraan lahir dan kebahagiaan batin.
Metode kontrasepsi yang paling banyak digunakan oleh peserta KB aktif adalah suntikan $(47,54 \%)$ dan terbanyak ke dua adalah pil (23,58\%). Sedangkan metode kontrasepsi yang paling sedikit dipilih oleh peserta KB aktif yaitu Metode Operasi Pria (MOP) sebanyak 0,69\%, kemudian kondom sebanyak 3,15\%. Data dan informasi mengenai KB aktif di Indonesia tahun 2014 dapat dilihat pada Lampiran 5.9. Sedangkan pada peserta $\mathrm{KB}$ baru, persentase metode kontrasepsi yang terbanyak digunakan yaitu suntikan sebesar $49,67 \%$. Metode terbanyak ke dua yaitu pil, sebesar 25,14\%. Metode yang paling sedikit dipilih oleh para peserta $\mathrm{KB}$ baru adalah metode operasi pria (MOP) sebanyak 0,21\%, kemudian metode operasi wanita (MOW) sebanyak 1,50\%, dan kondom (5,68\%) (BKKBN, 2015).

Provinsi dengan persentase peserta KB baru tertinggi ialah Provinsi DKI Jakarta (32,02\%), kemudian Papua $(29,74 \%)$, dan Bengkulu (27,34\%). Sedangkan provinsi dengan persentase peserta KB baru terendah ialah Provinsi Bali (9,90\%), DI Yogyakarta (9,99\%), dan Jawa Timur (13,27\%). Secara nasional, persentase peserta $\mathrm{KB}$ baru pada tahun 2014 sebesar 16,51\% (BKKBN, 2015). Metode suntikan KB telah menjadi bagian gerakan keluarga berencana 
nasional serta peminatnya makin bertambah. Tingginya minat pemakai suntikan KB oleh karena aman, sederhana, efektif, tidak menimbulkan gangguan dan dapat dipakai pada pasca persalinan. Kontrasepsi suntik mempunyai permasalahan atau efek samping. Pada pemakaian KB suntik mengalami beberapa permasalahan utama, yaitu gangguan pola haid. Gangguan pola haid yang terjadi tergantung pada lama pemakaian. Gangguan pola haid yang terjadi seperti perdarahan bercak, perdarahan irregular, amenore dan perubahan dalam frekuensi, lama dan jumlah (Manuaba, 2008).

Kelainan menstruasi menurut siklusnya dibagi menjadi menorea (25-31 hari), polimenorea (<35 hari), amenorea (tanpa haid lebih dari 3 bulan), menstruasi ireguler. Terjadinya menstruasi atau haid merupakan perpaduan antara kesehatan alat genetalia dan rangsangan hormonal yang kompleks yang berasal dari mata rantai aksis hipotalamus-hipofisisovarium. Oleh karena itu, gangguan haid dan gangguan siklus haid dapat terjadi dari kelainan kedua faktor tersebut (Manuaba, 2010). Bidan sebagai tenaga profesional kesehatan di bawah kementrian kesehatan merupakan pihak paling dekat dengan calon akseptor karena merupakan pemberi pelayanan pertama mulai dari KIE sampai dengan pemasangan alat kontrasepsi. Bidan mempunyai kewenangan memberikan asuhan keluarga berencana dan pendidikan kesehatan yang tanggap terhadap budaya dan menyeluruh dimasyarakat sebagai upaya dalam mengatasi masalah amenore tersebut dengan memberi penjelasan (konseling) kepada akseptor $\mathrm{KB}$ suntik, bahwa tidak teraturnya haid karena amenore merupakan salah satu efek samping penggunaan KB suntik DMPA yang tidak memerlukan pengobatan (Sulistyawati, 2011).

Berdasarkan hasil survey Januari April 2017 jumlah akseptor KB suntik 3 bulan di BPM Bidan "S" Curug Tangerang sebanyak 425 orang. Dari data tersebut didapat akseptor $\mathrm{KB}$ suntik 3 bulan yang tidak mengalami efek samping yaitu $23 \%$, dan yang mengalami efek samping dari KB suntik 3 bulan sebanyak $77 \%$, terdiri dari yang mengalami amenore sebanyak $75 \%$, yang mengalami kenaikan berat badan sebanyak 19,5\%, dan yang mengalami spoting $5,5 \%$.

\section{METODE}

Penelitian ini menggunakan metode deskriptif untuk mengetahui karakteristik akseptor KB suntik 3 buan dengan amenorea sekunder di BPM bidan "S" Curug Tangerang. Adapun variabel yang diteliti dalam pelitian ini 
berdasarkan usia, paritas, lama $\mathrm{KB}$, dan lama mengalami gangguan, penelitian dilakukan secara bersamaan pada tiap tiap variabel tersebut, yaitu dengan melihat rekam medik.

Populasi adalah keseluruhan objek penelitian atau objek yang diteliti dan dapat berupa orang, benda, gejala, atau wilayah yang ingin diketahui oleh peneliti (Notoatmodjo, 2012). Yang menjadi populasi pada penelitian ini adalah seluruh akseptor $\mathrm{KB}$ suntik 3 bulan di BPM Bidan "S" Curug Tangerang pada periode Januari - April 2017 yaitu sebanyak 425 orang. Dalam penelitian ini pengumpulan data yang digunakan dalam penelitian ini mengunakan data sekunder yang sudah dibuat sesuai dengan penelitian berdasarkan rekam medik di BPM bidan "S" Curug Tangerang.

\section{HASIL}

Data hasil penelitian tentang gambaran karakteristik akseptor $\mathrm{KB}$ suntik 3 bulan degan amenorea sekunder di BPM Bidan "S" Tangerang dengan jumlah sampel sebanyak 76 responden adalah sebagai berikut:

\section{Usia}

Tabel 1. Distribusi Frekuensi Akseptor KB Suntik 3 Bulan Dengan Amenorea Sekunder Berdasarkan Usia

\begin{tabular}{ccc}
\hline Usia & Jumlah & Persentase (\%) \\
\hline$<20$ & 1 & 1,3 \\
\hline $20-35$ & 56 & 73,7 \\
\hline$>35$ & 19 & 25 \\
\hline Total & $\mathbf{7 6}$ & $\mathbf{1 0 0 , 0}$ \\
\hline
\end{tabular}

Berdasarkan tabel 1 diketahui bahwa dari 76 akseptor $\mathrm{KB}$ suntik 3 bulan yang mengalami amenorea sekunder hampir tidak ada akseptor yang berusia kurang dari 20 tahun sebanyak 1 orang $(1,3 \%)$, lebih dari setengahnya akseptor yang berusia 2035 tahun sebanyak 56 orang $(73,7 \%)$, dan kurang dari setengahnya akseptor yang berusia $>35$ tahun sebanyak 19 orang $(25 \%)$. 


\section{Paritas}

Tabel 2. Distribusi Frekuensi Akseptor KB Suntik 3 Bulan Dengan Amenorea Sekunder Berdasarkan Paritas

\begin{tabular}{lcc}
\hline \multicolumn{1}{c}{ Paritas } & Jumlah & Persentase (\%) \\
\hline Primipara & 9 & 11,9 \\
\hline Multipara & 19 & 25 \\
\hline Grande Multipara & 48 & 63,1 \\
\hline \multicolumn{1}{c}{ Total } & $\mathbf{7 6}$ & $\mathbf{1 0 0 , 0}$ \\
\hline
\end{tabular}

Berdasarkan tabel 2 diketahui bahwa dari 76 akseptor KB suntik 3 bulan yang mengalami amenorea sekunder sebagian kecil akseptor primipara sebanyak 9 orang $(11,9 \%)$, kurang dari setengahnya akseptor multipara sebanyak 19 orang (25\%), dan lebih dari setengahnya akseptor grande multipara sebanyak 48 orang $(63,1 \%)$.

\section{Lama KB}

Tabel 3. Distribusi Frekuensi Akseptor KB Suntik 3 Bulan Dengan Amenorea Sekunder Berdasarkan Lama Ber-KB

\begin{tabular}{ccc}
\hline Lama ber-KB & Jumlah & Persentase (\%) \\
\hline $3-<12$ bulan & 10 & 13,1 \\
\hline $12-24$ bulan & 25 & 32,9 \\
\hline$>24$ bulan & 41 & 54 \\
\hline Total & $\mathbf{7 6}$ & $\mathbf{1 0 0 , 0}$ \\
\hline
\end{tabular}

Berdasarkan tabel 3 diketahui bahwa dari 76 akseptor KB suntik 3 bulan yang mengalami amenorea sekunder sebagian kecil akseptor dengan lama berKB $3-<12$ bulan sebanyak 10 orang $(13,1 \%)$, kurang dari setengahnya akseptor dengan lama berKB 12 - 24 bulan sebanyak 25 orang $(32,9 \%)$, dan lebih dari setengah akseptor dengan lama ber$\mathrm{KB} \geq 24$ bulan sebanyak 41 orang $(54 \%)$. 


\section{Lama Mengalami Gangguan Haid}

Tabel 4. Distribusi Frekuensi Akseptor KB Suntik 3 Bulan Dengan Amenorea Sekunder Berdasarkan Lama Mengalami Gangguan Haid

\begin{tabular}{ccc}
\hline $\begin{array}{c}\text { Lama Mengalami } \\
\text { Gangguan Haid }\end{array}$ & Jumlah & Persentase (\%) \\
\hline $3-5$ Bulan & 8 & 10,5 \\
\hline $6-11$ Bulan & 13 & 17,1 \\
\hline $1-5$ Tahun & 24 & 31,6 \\
\hline $6-10$ Tahun & 31 & 40,8 \\
\hline Total & $\mathbf{7 6}$ & $\mathbf{1 0 0 , 0}$ \\
\hline
\end{tabular}

Berdasarkan tabel 4 diketahui bahwa dari 76 akseptor KB suntik 3 bulan dengan amenorea sekunder sebagian kecil akseptor mengalami gangguan haid $3-5$ bulan sebanyak 8 orang $(10,5 \%)$, sebagian kecil akseptor mengalami gangguan haid 6 - 11 bulan sebanyak 13 orang $(17,1 \%)$, kurang dari setengahnya akseptor mengalami gangguan haid 1 - 5 tahun sebanyak 24 tahun $(31,6 \%)$, dan kurang dari setengahnya mengalami gangguan haid $6-10$ tahun sebanyak 31 orang $(40,8 \%)$.

\section{DISKUSI}

\section{Usia}

Berdasarkan hasil penelitian dari 76 akseptor $\mathrm{KB}$ suntik 3 bulan yang mengalami amenorea sekunder hampir tidak ada akseptor yang berusia kurang dari 20 tahun sebanyak 1 orang (1,3\%), lebih dari setengahnya akseptor yang berusia 2035 tahun sebanyak 56 orang $(73,7 \%)$, dan kurang dari setengahnya akseptor yang berusia >35 tahun sebanyak 19 orang $(25 \%)$. Hal tersebut sesuai dengan penelitian Depkes RI (2014), yang mengatakan masa reproduksi sehat wanita dibagi menjadi 3 periode yaitu kurun reproduksi muda (15-19 tahun) merupakan tahap menunda kehamilan, kurun reproduksi sehat (20-35 tahun) merupakan tahap untuk menjarangkan kehamilan dimana pengguna $\mathrm{KB}$ akan meningkat pada usia reproduksi muda, dan kurun reproduksi tua (36-45tahun) merupakan tahap untuk mengakhiri kehamilan. Menurut Yanuar 2010 dalam Antika (2014) usia seseorang menentukan metode kontrasepsi yang akan dipilih, semakin tua usia seseorang akan meningatkan kemungkinan untuk tidak menginginkan kehamilan lagi, serta memilih metode kontrasepsi yang cocok dan efektif. Setelah dilihat hasil penelitian dan dibandingkan dengan 
teori bahwa penelitian dan teori tidak ada kesenjangan.

\section{Paritas}

Berdasarkan hasil penelitian dari 76 akseptor KB suntik 3 bulan yang mengalami amenorea sekunder sebagian kecil akseptor primipara sebanyak 9 orang $(11,9 \%)$, kurang dari setengahnya akseptor multipara sebanyak 19 orang (25\%), dan lebih dari setengahnya akseptor grande multipara sebanyak 48 orang $(63,1 \%)$. Menurut Basyir (2002) dalam Rauf (2014) menyatakan bahwa ada pengaruh paritas terhadap penggunaan kontrasepsi suntik karena akseptor tersebut baru memutuskan untuk menjadi akseptor setelah memiliki anak lebih dari 3 orang dan mulai menyadari beban keluarga yang semakin meningkat. Dengan jumlah anak yang semakin banyak maka kebutuhan ekonomi akan semakin meningkat. sehingga diketahui bahwa ada pengaruh paritas pada penggunaan KB suntik 3 bulan.

\section{Lama KB}

Berdasarkan hasil penelitian dari 76 akseptor KB suntik 3 bulan yang mengalami amenorea sekunder sebagian kecil akseptor dengan lama berKB $<12$ bulan sebanyak 10 orang
$(13,1 \%)$, kurang dari setengahnya akseptor dengan lama berKB 12-24 bulan sebanyak 25 orang $(32,9 \%)$, dan lebih dari setengah akseptor dengan lama berKB $\geq 24$ bulan sebanyak 41 orang (54\%). Hal di atas sesuai dengan Hartanto (2010), yang mengatakan gangguan pola haid yang terjadi tergantung lama pemakaian. Gangguan pola haid yang terjadi seperti perdarahan bercak, perdarahan iregular, amenorea dan perubahan dalam frekuensi, lama dan jumlah darah yang hilang dan Efek pemakaian $\mathrm{KB}$ suntik tiga bulan terhadap amenorea bertambah besar seiring dengan lamanya waktu pemakaian KB suntik tiga bulan. Menurut Sunardiningtyas (2013) Semakin lama penggunaan $\mathrm{KB}$ suntik 3 bulan, maka kejadian lama menstruasi menjadi berubah tidak menstruasi sama sekali. Perubahan lama menstruasi tersebut disebabkan komponen gestagen yang terkandung di dalam progesteron. Perubahan ini sejalan dengan berkurangnya darah menstruasi pada akseptor KB suntik 3 bulan bisa merupakan tanda suatu kehamilan.

Berdasarkan hasil penelitian yang dilakukan oleh Nurlaila dipuskesmas keratonan Surakarta (2010), pemakaian kontrasepsi DMPA 
selama $\geq 24$ tahun mempunyai risiko 5,2 kali untuk mengalami amenorea sekunder bila dibandingkan dengan pemakaian selama 3-12 bulan. Sedangkan lama pemakaian kontrasepsi DMPA selama 12-24 bulan mempunyai 5,11 kali untuk mengalami amenorea sekunder dibandingkan dengan pemakaian selama 3-12 bulan. Setelah dilihat hasil penelitian dan dibandingkan dengan teori bahwa penelitian dan teori tidak ada kesenjangan.

\section{Lama Mengalami Gangguan}

Berdasarkan hasil penelitian dari 76 akseptor KB suntik 3 bulan dengan amenorea sekunder sebagian kecil akseptor mengalami gangguan haid 3 5 bulan sebanyak 8 orang (10,5\%), sebagian kecil akseptor mengalami gangguan haid 6-11 bulan sebanyak 13 orang $(17,1 \%)$, kurang dari setengahnya akseptor mengalami gangguan haid 1-5 tahun sebanyak 24 tahun (31,6\%), dan kurang dari setengahnya mengalami gangguan haid 6 - 10 tahun sebanyak 31 orang (40,8\%). Hal ini sesuai dengan pendapat Hartanto (2010) mengatakan bahwa amenorea sekunder merupakan gangguan menstruasi yang sering dikeluhkan peserta KB suntik 3 bulan. Kondisi amenorea ini dilaporkan terjadi setelah 3 bulan pemakaian sebesar $30 \%$, kemudian menjadi $55 \%$ pada akhir satu tahun pemakaian dan akhirnya menjadi $68 \%$ setelah dua tahun pemakaian KB suntik 3 bulan. Setelah dilihat hasil penelitian dan di bandingkan dengan teori bahwa penelitian dan teori tidak ada kesenjangan.

\section{SIMPULAN}

1. Berdasarkan usia dari 76 akseptor $\mathrm{KB}$ suntik 3 bulan yang mengalami amenorea sekunder lebih dari setengahnya akseptor yang berusia 2035 tahun sebanyak 56 orang $(73,7 \%)$ dan paling sedikit berusia kurang dari 20 tahun sebanyak 1 orang $(1,3 \%)$.

2. Berdasarkan paritas dari 76 akseptor KB suntik 3 bulan yang mengalami amenorea sekunder lebih dari setengahnya akseptor grande multipara sebanyak 48 orang $(63,1 \%)$, dan sebagian kecil akseptor primipara sebanyak 9 orang $(11,9 \%)$.

3. Berdasarkan lama ber-KB dari 76 akseptor KB suntik 3 bulan yang mengalami amenorea sekunder lebih dari setengah akseptor dengan lama ber-KB $\geq 24$ bulan sebanyak 41 orang (54\%). Dan sebagian kecil akseptor dengan lama ber-KB 3-<12 bulan sebanyak 10 orang $(13,1 \%)$. 
4. Berdasarkan lama mengalami gangguan dari 76 akseptor KB suntik 3 bulan yang mengalami amenorea sekunder kurang dari setengahnya mengalami gangguan haid $6-10$ tahun sebanyak 31 orang $(40,8 \%)$, kecil akseptor mengalami gangguan haid $3-5$ bulan sebanyak 8 orang $(10,5 \%)$

\section{DAFTAR PUSTAKA}

Anwar, M. Ali Baziad. Prajitno Prabowo. 2011. Ilmu Kandungan. Jakarta : Bina Pustaka Sarwono Prawirohardjo.

Brahm. 2012. Ragam Metode Kontrasepsi. Jakarta : EGC

Sunardianingtyas, Bulan Novita. 2012. Tingkat pengetahuan akseptor KB suntik 3 bulan tentang amenore sekunder akibat pemakaian KB suntik 3 bulan di BPS Titin Listyowati Gondang Sragen. Di dapat dari Online Available : http://stikeskusumahusada.ac.id diakses pada tanggal 12 Mei 2017.

Burns, A. 2009. Kesehatan Reproduksi Prempuan dan Metode KB yang Tepat untuk Anda. Yogyakarta : KDT

Depkes RI. 2012. Pusat Data dan Informasi Profil Kesehatan Indonesia 2014. di dapat dari Online Avaible : http://www.kemkes.go.id diakses tanggal 13 Mei 2017.

Ernawati, Widiastini, 2012. Agustini. Hubungan antara lama pemakaian $\mathrm{KB}$ suntik 3 bulan dengan gangguan menstruasi di puskesmas mengwi II bandung. di dapat dari Online Available http://biofarmaka.ipb.ac.id diakses pada tanggal 08 April 2017.
Everett, S. 2012. Kontrasepsi dan Kesehatan Seksual Reproduktif. Jakarta : EGC.

Glasier, A. Alisa Gebbie. 2012. Keluarga Berencana dan Kesehatan Repsoduksi. Jakarta : EGC.

Hartanto. 2010. Keluarga Berencana dan Kontrasepsi. Jakarta : Pustaka Sinar Harapan.

Irianti, B. dkk. 2014. Asuhan kehamilan berbasis bukti paradigma baru dalam asuhan kebidanan. Jakarta : Sagung seto.

Manuaba, C. Fajar Manuaba. 2008. Gawat Darurat Obsteri Ginekologi dan Obstetri Ginekologi Sosial untuk Profesi Bidan. Jakarta : EGC.

Manuaba, I.A.C, dkk. 2009. Memahami Kesehatan Reproduksi Wanita. Jakarta : EGC.

Notoatmodjo, S.2012. Metodologi Penelitian Kedokteran. Jakarta : Rineka Cipta.

Nurlaila, S. 2013. Hubungan lama pemakaian kontrasepsi depo medroxy progesterone acetat dengan kejadian amenorea sekunder di puskesmas kratonan surakarta. Surakarta : Fakultas kedokteran universitas sebelas maret Surakarta.

Octasari dan Yusniwarti. 2014. Hubungan jenis dan lama penggunaan alat kontrasepsi hormonal terhadap gangguan menstruasi pada ibu PUS di kelurahan binjai kecamatan medan denai 2014. Di dapat dari Online Available http://202.0.107.5index.phpgkrearti cleview76004320 diakses pada 12 Mei 2017.

Prawirohardjo, S. 2010. Buku Panduan Praktis Pelayanan Kontrasepsi. Jakarta : Yayasan Bina Pustaka Sarwono Prawirohardjo.

Rauf, SKD. 2012. Faktor-faktor yang mempengaruhi penggunaan kontrasepsi suntik pada akseptor KB dipuskesmas bungoro kabupaten pangkep. Didapat dari Online Available 
http://stikesnh.ac.id diakses pada tanggal 26 mei 2017.

Rika Margiyanti. 2012. Asuhan kebidanan akseptor KB suntik 3 bulan pada Ny.W dengan amenorea di BPS siti murwani batuwarno wonogiri 2013. Di dapat dari Online Available : http://www.stikesusumahusada.ac.id diakses pada 12 Mei 2017.

Sastroasmoro, S. 2008. Sofyan Ismael. Dasar-Dasar Metodelogi Penelitian Klinis. Jakarta : Sagung seto.

Sulistyawati, A. 2011. Pelayanan Kelurga Berencana. Jakarta : Salemba Medika.

Tiran, D. 2006. Kamus Saku Bidan. Jakarta: EGC.

Wiknjosastro, H. 2010. Ilmu Kebidanan. Jakarta : Yayasan Bina Pustaka Sarwono Prawirohardjo. 